\title{
Tax laws impede joint project by US and Japan
}

Tokyo. Japan's tax laws are standing in the way of a pioneering attempt by Japan and the United States to give their computer designers access to the most advanced optoelectronic devices under development in company and government research laboratories in both countries.

As part of Japan's Real World Computing programme, a 10-year US\$700-million initiative by the Ministry of International Trade and Industry (MITI) to develop new massively parallel computers, the United States and Japan signed an agreement in June to establish the US-Japan Optoelectronics Project (JOP), which is expected to begin in October.

The project provides a broker service in each country to bring together suppliers of new optoelectronic devices under development in the laboratory on the one hand, and designers of advanced computer systems who will evaluate the devices in experimental prototype machines on the other. (These designers could work in private or government laboratories, or in universities.)

In Japan, the broker system is run by the Optoelectronics Industry and Technology Development Association. In the United States a broker system will be set up shortly by the National Institute of Standards and Technology.

Japan is a recognized world leader in optoelectronics, and government officials on both sides expect the flow of devices to be predominantly from Japan to the United States. But tax regulations in Japan are making it very difficult for Japanese companies to provide US users with devices.

Companies in Japan are given a tax break on their research and development expenditure to encourage them to spend even more. Twenty per cent of any annual increase in a company's research and development expenditure is tax-deductible - but only if the company research institutes do not engage in any commercial activity.

Under the broker system, users pay for the devices to which they are given access and also enter into agreements on intellectual property rights. But the Japanese companies producing the devices in the laboratory cannot sell them without losing their research and development tax privileges.

To avoid infringing tax laws, US and Japanese government officials have agreed that, although the devices must be the latest technology coming out of company laboratories, they can be provided by the laboratory to a commercial arm of the company, then sold by this unit to the JOP broker.

But this has led to other problems, says Kazuo Kyuma of Mitsubishi Electric's central research laboratory in Osaka. Kyuma has been approached by a delegation of US government officials from various agencies, including the Department of Defense, seeking access to a novel artificial retina chip, developed by Kyuma, that detects and processes images in much the same way as the human eye.

Mitsubishi cannot yet mass-produce the retina chip in its factories because the device is still under development and not ready for large-scale production. Kyuma can produce the devices in his laboratory and transfer them to a Mitsubishi factory for sale to US users through the JOP broker system, but the company is concerned about the quality of the laboratory-produced devices.

Kyuma says the situation in Japan is quite different from that in the United States where company laboratories often produce and sell devices. In Japan, company research institutes never do this because of tax regulations and they are thus not geared up to produce reliable devices for sale.

Kyuma believes that the most likely so-

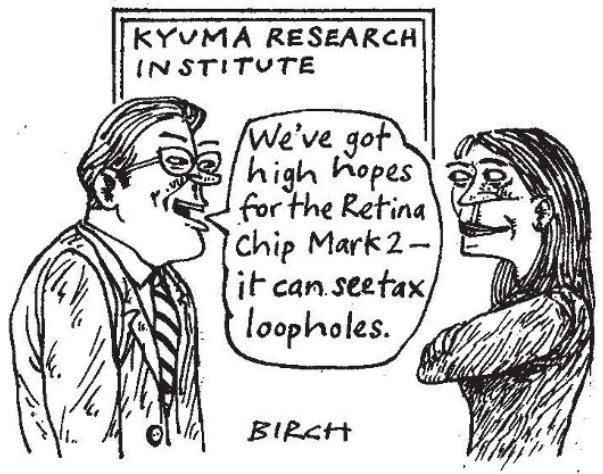

lution is that his laboratory will supply the devices to US users through a Mitsubishi factory with the understanding that they may not have the same reliability as factorymade components.

\section{India set to end 'gene robbery'}

New Delhi. International drug companies will no longer have free access to India's genetic wealth. A tough new law, which comes into force next year, will prevent foreign companies from helping themselves to commercially valuable genes.

The new legislation names more than 9,000 medicinal plants, in addition to industrially important microbes, that will no longer be allowed to leave India. It will be illegal to export crop germ plasm without a bilateral 'exchange' agreement with the state-owned national gene bank.

Officials from the Ministry for Environment and Forests (MEF) say that in the absence of any regulatory mechanisms, foreign agencies, particularly drug companies, have been plundering India's genetic resources for their own benefit.

They cite Rauwolfia serpentina as an example. This plant provides raw material for an antihypertensive drug whose annual sales are US\$260 million in the United States alone, but India does not get any share of the profit, they say. And, the American Type Culture Collection in Maryland has more than 380 fungal and 90 bacterial accessions from India, some of them patented.

Speaking recently at a meeting of the Indian Academy of Sciences on protection of intellectual property rights, Palpu Pushpangadan, director of the tropical botanical gardens in Trivandrum, claimed that US and Japanese companies had often taken away soil samples, along with soil microorganisms, from different ecosystems in India, without any form of control.

Pushpangadan, who is also president of the National Society of Ethnopharmacology, has data on 7,500 medicinal plants that have been used as folk remedies. But to prevent foreign companies from exploiting these plants, his research institute in Trivandrum - under instruction from MEF - is to withhold the information from electronic databases to which foreigners have access.

The international scramble for India's genetic diversity came into focus last week when two Germans, claiming to be tourists, were caught trying to smuggle more than 30,000 insects of various types out of Delhi airport. They are awaiting charges.

MEF officials say the new legislation will end what they call "gene robbery" and ensure that India gets compensation from companies that market products using India's genetic material.

Controlling the country's genetic wealth has become crucial, particularly after the conclusion last year of the General Agreement on Tariffs and Trade, which allows patenting of genes and microorganisms. In addition, India is a signatory to the biodiversity convention which gives states sovereign rights over their biological resources. This is why India has the right to restrict access to its gene pools, say officials.

India has also taken steps recently to get back some of the materials it has already lost. Two months ago, the International Rice Research Institute in Manila in the Philippines agreed to return to India 5,000 accessions of traditional rice strains from Assam state, which were taken away by the institute in the 1960s. The United States will similarly be asked to return duplicates of all crop germ plasm it has collected from India between 1950 and 1970.

K. S. Jayaraman 